\title{
ANALISIS FAKTOR-FAKTOR YANG MEMPENGARUHI INVESTMENT OPPORTUNITY SET DAN IMPLIKASINYA TERHADAP RETURN SAHAM
}

\author{
Dian Kusumawati ${ }^{1}$, Muhammad Safiq ${ }^{2}$ \\ PT Arthamas Cipta Jakarta ${ }^{1}$ \\ President University ${ }^{2}$ \\ diankusumajr@gmail.com
}

\begin{abstract}
Abstrak- Penelitian ini bertujuan untuk menguji struktur modal, ukuran perusahaan, pertumbuhan penjualan, profitabilitas, likuiditas, investment opportunity set dan return saham. Penelitian ini dilakukan pada 30 perusahaan properti dan real estate yang terdaftar di Bursa Efek Indonesia pada periode pengamatan 2013-2017 dengan jumlah sampel 150 perusahaan properti dan real estate. Teknik pengumpulan data menggunakan metode dokumentasi di situs resmi bursa efek indonesia dan yahoo finance. Data penelitian ini menggunakan data panel, dan untuk menguji variabel intervensi dengan Structural Equation Model (SEM). Hasilnya adalah struktur modal tidak memiliki pengaruh pada investment opportunity set; ukuran perusahaan tidak memiliki pengaruh pada investment opportunity set; pertumbuhan penjualan tidak memiliki pengaruh pada investment opportunity set; profitabilitas memiliki pengaruh pada investment opportunity set; likuiditas memiliki pengaruh pada investment opportunity set; dan faktor-faktor yang mempengaruhi investment opportunity set mampu meningkatkan pengaruh investment opportunity set terhadap return saham. Hal ini digambarkan dengan hubungan profitabilitas, investment opportunity set dan return saham yang berpengaruh signifikan dan hubungan struktur modal, investment opportunity set dan return saham yang berpengaruh signifikan.
\end{abstract}

Kata Kunci : Struktur Modal, Ukuran Perusahaan, Pertumbuhan Penjualan, Profitabilitas, Likuiditas, Investment Opportunity Set Dan Return Saham

\section{PENDAHULUAN}

Tujuan investor menanamkan dananya di pasar modal adalah untuk mencari keuntungan semaksimal mungkin dengan mengkombinasikan berbagai risiko investasi. Pasar modal sendiri didefinisikan sebagai pasar untuk berbagai instrument keuangan (sekuritas) jangka panjang yang bisa di perjualbelikan, baik dalam bentuk hutang maupun modal itu sendiri, baik yang diterbitkan pemerintah, public authorities, maupun 
perusahaan swasta (Husnan,2015:1). Salah satu produk pasar modal adalah saham, pergerakan harga saham yang terjadi dapat membuat investor memperoleh pendapatan atau return. Return yang diperoleh investor atas dananya yang diinvestasikan pada saham berupa bagian laba (dividen) dan selisih harga jual saham dengan harga belinya (capital gain).

Dalam memilih investasi yang menghasilkan keuntungan (return), investor memerlukan berbagai informasi sebagai landasan keputusan. Analisis investasi saham merupakan hal yang mendasar untuk diketahui investor karena tanpa adanya analisis yang baik dan rasional maka investor akan mengalami kerugian. Analisis investasi saham dapat dibedakan menjadi dua pendekatan yaitu analisis teknikal dan analisis fundamental. Analisis teknikal merupakan upaya untuk memperkirakan harga saham dengan mengamati perubahan harga saham tersebut di waktu yang lalu, analisis teknikal tidak memperhatikan faktor-faktor fundamental (Husnan,2015:341), sedangkan analisis fundamental memperkirakan harga saham di masa yang akan datang dengan mengestimasi nilai faktor-faktor fundamental yang mempengaruhi harga saham di masa yang akan datang dan menerapkan hubungan variabel-variabel tersebut sehingga diperoleh taksiran harga saham (Husnan, 2015:307).

Purwitajati (2016) menyatakan pergerakan harga saham dipengaruhi oleh variabel-variabel ekonomi makro dan variabel-variabel yang berasal dari internal perusahaan yang mencerminkan kinerja perusahaan. Kinerja perusahaan juga dapat dilihat dari nilai perusahaan, nilai perusahaan tersebut dibentuk melalui nilai pasar saham yang dipengaruhi oleh peluang-peluang investasi. Seperti yang diungkapkan Hartono (2016:58) kesempatan investasi atau Invesment Opportunity Set (IOS) menggambarkan tentang luasnya kesempatan atau peluang investasi bagi suatu perusahaan. Set kesempatan investasi menunjukkan kemampuan perusahaan memperoleh keuntungan dari prospek pertumbuhan.

Pertumbuhan perusahaan merupakan suatu harapan penting yang diinginkan oleh pihak internal perusahaan yaitu manajemen maupun eksternal perusahaan seperti investor dan kreditur. Pertumbuhan diharapkan dapat memberikan aspek yang positif bagi perusahaan sehingga meningkatkan kesempatan berinvestasi di perusahaan tersebut. Bagi investor pertumbuhan perusahaan merupakan suatu prospek yang menguntungkan, karena investasi yang ditanamkan diharapkan akan memberikan return 
yang tinggi di masa yang akan datang. Perusahaan yang tumbuh akan direspon pasar dan peluang pertumbuhan terlihat pada peluang investasi yang diproksikan dengan berbagai macam kombinasi nilai investment opportunity set.

Nilai IOS dapat dihitung dengan kombinasi berbagai jenis proksi yang mengimplikasikan nilai aktiva di tempat yaitu berupa nilai buku aktiva maupun ekuitas dan nilai kesempatan untuk bertumbuh bagi suatu perusahaan di masa depan. Hal ini dikarenakan Investment Opportunity Set (IOS) atau set kesempatan investasi dari suatu perusahaan mempengaruhi cara pandang manajer, pemilik, investor dan kreditor terhadap perusahaan. (Hidayah,2015).

Teori mengenai struktur modal adalah pecking order theory. Pecking order theoryi menjelaskan mengapa perusahaan akan menentukan sumber pendanaan yang paling disukai. Perusahaan lebih cenderung untuk menggunakan sumber pendanaan internal yaitu dari laba ditahan dan depresiasi terlebih dahulu, dari pada dana eksternal dalam aktivitas pendanaan kecuali saat perusahaan tidak memiliki dana internal yang memadai maka dana eksternal akan dipilih sebagai alternatifnya dan saat dana eksternal dipilih maka akan lebih cenderung menggunakan hutang dari pada ekuitas (Erosvitha, 2016).

Dalam upaya peningkatan pertumbuhan perusahaan, aspek modal merupakan hal yang perlu dipertimbangkan. Penentuan proporsi hutang dan modal dalam penggunaannya sebagai sumber dana perusahaan berkaitan erat dengan istilah struktur modal. Struktur modal yang tidak efisien akan menimbulkan biaya tetap dalam bentuk biaya modal yang tinggi, yang selanjutnya dapat berdampak pada hilangnya kesempatan bagi perusahaan untuk memanfaatkan laba dalam kepentingan pertumbuhan perusahaan. Margaretha (2011:112) menyatakan struktur modal optimal merupakan struktur modal yang mengoptimalkan keseimbangan antara risk dan return sehingga memaksimalkan harga saham. Pernyataan tersebut menunjukan maksimalnya harga saham berarti maksimal juga nilai perusahaannya. Karena harga pasar saham mencerminkan nilai perusahaan, dengan demikian jika nilai suatu perusahaan meningkat, harga pasar saham tersebut juga naik (Sudana, 2011:143).

Semakin tinggi hutang menunjukkan bahwa struktur pemodalan yang dimiliki oleh suatu perusahaan lebih banyak berasal dari hutang daripada modal sendiri. Hal ini menunjukkan semakin besar ketergantungan perusahaan terhadap pihak luar (kreditur) 
sehingga tingkat risiko perusahaan semakin besar. Ketika risiko yang dimiliki suatu perusahaan tinggi, maka akan mengakibatkan para investor menghindari untuk berinvestasi pada perusahaan dengan nilai hutang yang tinggi dan selanjutnya berakibat pada menurunnya nilai (return) saham perusahaan (Purwitajati, 2016). Walaupun demikian, penggunaan hutang tidak selamanya berdampak negatif, kebijakan pendanaan perusahaan yang berpotensi tumbuh tinggi memiliki tingkat hutang yang tinggi, karena pada perusahaan yang berpotensi tumbuh tinggi mempunyai kesempatan investasi yang tinggi sehingga membutuhkan dana yang tinggi dimana tidak cukup jika hanya didanai dari internal perusahaan.

Pilihan investasi dimasa mendatang terkait dengan tingkat pertumbuhan perusahaan. Pertumbuhan perusahaan diharapkan akan memberikan aspek yang positif bagi perusahaan seperti adanya suatu kesempatan berinvestasi dimasa mendatang. Peluang pertumbuhan itu akan terlihat pada kesempatan investasi yang diproksikan dengan berbagai kombinasi nilai investment opportunity set. Perusahaan yang melakukan berbagai pilihan investasi memberikan sinyal bahwa perusahaan tersebut sedang dalam masa tumbuh (Handriani,2015). Kesempatan investasi memberikan sinyal positif terhadap pertumbuhan perusahaan dimasa yang akan datang. Esensi pertumbuhan adalah adanya kesempatan investasi di masa datang yang dapat meningkatkan nilai perusahaan. Prospek perusahaan yang sedang bertumbuh bagi investor merupakan suatu prospek yang menguntungkan, karena investasi yang ditanamkan diharapkan akan memberikan return yang tinggi.

Perusahaan besar dinilai mampu meningkatkan kesempatan investasi perusahaan dengan adanya aset dan pendanaan yang memadai, hal ini membuat investor akan lebih meyakini perusahaan yang berukuran besar untuk menanamkan kelebihan dananya, karena sangat kecil kemungkinan akan terjadi kebangkrutan daripada menanamkan modalnya pada perusahaan kecil. Hal tersebut menunjukkan semakin banyak investor yang berniat membeli saham perusahaan yang berukuran besar maka harga saham perusahaan tersebut menjadi naik dan tingkat return saham juga meningkat. Hal ini sebanding dengan pernyataan Adiwibowo (2018), semakin besar ukuran perusahaan akan mencerminkan pula semakin besar kemampuan perusahaan untuk dapat membiayai kebutuhan dananya (kesempatan investasi) pada masa yang akan datang. 
Kinerja perusahaan mencakup kinerja keuangan dan kinerja non keuangan. kinerja keuangan yang baik menunjukan tingkat efektivitas manajemen suatu perusahaan dalam menghasilkan laba baik dari penjualan maupun kesempatan investasi yang telah dilakukan. Perusahaan yang memiliki keuntungan yang tinggi akan menjadi daya tarik bagi investor dan calon investor untuk menanamkan dananya ke perusahaan tersebut. Dengan semakin besarnya daya tarik ini akan maka akan banyak investor yang menginginkan saham perusahaan tersebut. Jika banyak permintaan atas saham suatu perusahaan maka harga sahamnya akan meningkat, peningkatan harga saham berdampak pada meningkatnya return yang diperoleh investor.

Keuntungan perusahaan diproksikan dengan profitabilitas, profitabilitas menunjukkan kemampuan perusahaan untuk menghasilkan laba. Profitabilitas yang lebih tinggi memungkinkan perusahaan untuk mempertahankan keberadaannya di industri pilihan mereka. Lebih jauh, semakin besar kemampuan laba perusahaan, semakin besar kemungkinan laba ditahan untuk tujuan investasi (Utama dan Sulistika,2015). Selain informasi keuntungan investor juga memperhatikan likuiditas perusahaan, seperti yang diungkapkan Sawir (2012:10) Current ratio yang rendah biasanya dianggap menunjukkan terjadinya masalah dalam likuidasi, sebaliknya jika current ratio terlalu tinggi dianggap kurang baik karena menunjukkan bahwa banyaknya dana yang tidak terpakai yang akhirnya dapat mengurangi kemampulabaan perusahaan.

Sektor yang digunakan dalam penelitian ini yaitu sektor properti dan real estate . Perusahaan properti dan real estate merupakan perusahaan yang bergerak dibidang jasa properti dan real estate. Alasan dalam pemilihan sektor properti dan real estate dikarenakan saham dalam sektor ini merupakan saham-saham yang mampu bertahan terhadap perubahan kondisi lingkungan ekonomi atau krisis ekonomi dibandingkan sektor lain. Tingkat pertumbuhan industri properti dan real estate di Indonesia pasca krisis moneter cenderung meningkat, peningkatan ini terutama digerakkan oleh banyaknya pembangunan pusat-pusat perdagangan serta gedung-gedung perkantoran. Bisnis properti merupakan salah satu usaha yang hampir dapat dipastikan tidak akan pernah mati karena kebutuhan akan papan atau tempat tinggal merupakan kebutuhan pokok manusia, dan setiap manusia akan berusaha untuk dapat memenuhinya. Hal ini di gambarkan pada total angka penjualan tahunan sektor properti dan real estate tahun 
2013 sebesar Rp 55 triliun, tahun 2014 sebesar Rp 65 triliun , 2015 sebesar Rp 72 triliun, tahun 2016 sebesar Rp 68 triliun dan mencapai Rp 76 triliun pada akhir 2017. Walaupun sempat menurun pada tahun 2016, namun pada tahun-tahun lainnya cenderung meningkat. Berikut ini akan disajikan data mengenai rata-rata return saham, Long term debt to equity ratio, total assets, return on equity, dan current rasio Perusahaan Properti dan Real Estate di Bursa Efek Indonesia Tahun 2013 - 2017.

\section{Tabel 1.1}

Data Rata-Rata Return Saham, Long Term Debt to Equity Ratio, Total Assets, ROE, Current Ratio dan IOS

Perusahaan Properti dan Real Estate di Bursa Efek Indonesia Tahun 2013-2017

\begin{tabular}{|l|c|c|c|c|c|c|c|}
\hline Tahun & $\begin{array}{l}\text { Return } \\
\text { Saham }\end{array}$ & LTD & $\begin{array}{c}\text { TA } \\
\text { (Jutaan Rp) }\end{array}$ & ROE & CR & $\begin{array}{c}\text { Sales } \\
\text { Growth }\end{array}$ & IOS \\
\hline 2013 & $43.06 \%$ & $37.28 \%$ & $222,892,136$ & 0.16 & 2.45 & $52.01 \%$ & $165 \%$ \\
\hline 2014 & $34.95 \%$ & $39.05 \%$ & $261,697,594$ & 0.14 & 2.19 & $18.08 \%$ & $197 \%$ \\
\hline 2015 & $-9.47 \%$ & $41.56 \%$ & $301,732,861$ & 0.12 & 2.29 & $24.39 \%$ & $164 \%$ \\
\hline 2016 & $-1.28 \%$ & $41.73 \%$ & $326,854,409$ & 0.10 & 2.54 & $-0.73 \%$ & $142 \%$ \\
\hline 2017 & $5.05 \%$ & $47.30 \%$ & $372,748,084$ & 0.10 & 2.72 & $4.10 \%$ & $152 \%$ \\
\hline
\end{tabular}

Sumber : Yahoo Finance, situs resmi perusahaan dan www.idx.co.id, data di olah.

Berdasarkan Tabel 1.1, dapat terlihat pergerakan return saham mengalami penurunan pada kurun waktu 2013-2016, dalam periode ini pergerakan Long term debt to equity ratio (LTD) mengalami kenaikan, namun pada tahun 2016-2017 ketika return saham mengalami kenaikan hutang juga mengalami kenaikan hal ini menggambarkan bahwa hutang tidak mempengaruhi return saham. Hal ini sesuai dengan hasil penelitian Milka,dkk (2019) yang menyatakan bahwa hutang tidak berpengaruh terhadap return saham. Sementara Purwitajati (2016) berpendapat bahwa semakin tinggi hutang menunjukkan semakin besar ketergantungan perusahaan terhadap pihak luar (kreditur) sehingga tingkat risiko perusahaan semakin besar. Ketika risiko yang dimiliki suatu perusahaan tinggi, maka akan mengakibatkan para investor menghindari untuk berinvestasi pada perusahaan dengan nilai hutang yang tinggi dan selanjutnya berakibat pada menurunnya nilai (return) saham perusahaan. Hal ini didukung oleh pendapat yang 
diungkapkan oleh Purwitajati,dkk (2016) dalam hasil penelitiannya bahwa hutang memiliki pengaruh terhadap return saham.

Nilai aset perusahaan selama periode 2013-2017 mengalami fluktuasi, namun pada tahun 2013-2015 saat nilai aset mengalami kenaikan, return saham justru mengalami penurunan sedangkan pada tahun 2016-2017 ketika return saham mengalami kenaikan, asset tetap mengalami kenaikan. Hal ini serupa dengan penelitian Raningsih,dkk (2015) dan Asri,dkk (2014) yang mengungkap bahwa ukuran perusahaan tidak berpengaruh terhadap return saham. Namun penelitian ini bertentangan dengan hasil penelitian Putra,dkk (2016) yang menyatakan bahwa ukuran perusahaan berpengaruh terhadap return saham.

Pada tahun 2013-2015 terjadi penurunan return saham dan ROE, namun pada tahun 2016-2017 ketika return saham mengalami peningkatan ROE mengalami penurunan. Serupa dengan hasil penelitian Aisah,dkk (2016) yang menyatakan profitabilitas tidak berpengaruh terhadap return saham. Hal ini berbanding terbalik dengan yang diungkapkan Fahmi (2014:116) semakin baik rasio profitabilitas maka semakin baik menggambarkan kemampuan tingginya perolehan keuntungan perusahaan. Jika perusahaan dapat menghasilkan laba yang tinggi, maka permintaan akan saham meningkat dan selanjutnya akan berdampak pada meningkatnya harga saham perusahaan. Ketika harga saham semakin meningkat maka return saham juga akan meningkat yang di setujui dengan hasil penelitian Ashari,dkk (2018) yang menyatakan profitabilitas berpengaruh terhadap return saham.

Pada tahun 2015 ketika return saham mengalami penurunan, current ratio mengalami peningkatan. Hal ini sesuai dengan yang diungkapkan oleh Hanafi dan Halim (2012:202) suatu perusahaan yang memiliki rasio lancar terlalu tinggi juga kurang bagus, karena menunjukkan banyaknya dana menganggur yang pada akhirnya dapat mengurangi kemampulabaan (return) perusahaan.. Hasil penelitian terdahulu juga terdapat perbedaan seperti yang diungkapkan dalam penelitian Prince et al, (2014) yang menyatakan bahwa current ratio berpengaruh signifikan terhadap return saham, sebaliknya Febrioni (2016) menyatakan current ratio tidak berpengaruh signifikan terhadap return saham.

Pertumbuhan penjualan (sales growth) pada tahun 2015 mengalami kenaikan disaat return saham mengalami penurunan, namun pada tahun 2016 ketika return saham 
mengalami kenaikan justru pertumbuhan penjualan mengalami penurunan. Hal ini menggambarkan bahwa pertumbuhan penjualan tidak mempengaruhi return saham, seperti yang diungkapkan oleh Nurmasari (2017) dalam penelitiannya bahwa sales growth tidak berpengaruh terhadap return saham, namun hal ini berbalik dengan yang diungkapkan Andriasari,dkk (2016) dalam penelitiannya berpendapat bahwa sales growth berpengaruh signifikan terhadap return saham.

Pada periode 2013-2017, IOS mengalami fluktuasi. Pada tahun 2014, ketika return saham mengalami penurunan IOS mengalami kenaikan. Namun pada tahun 2016, ketika return saham mengalami kenaikan justru IOS mengalami penurunan. Hal ini sesuai dengan penelitian Herdyan et. al. (2017) yang menunjukan investment opportunity set tidak berpengaruh signifikan terhadap return saham. Sebaliknya Safitri (2015) menyatakan investment opportunity set yang ada bagi perusahan merupakan faktor utama yang yang menentukan pergerakan harga saham. Hal ini didukung oleh hasil penelitian Puteri,dkk (2012) menemukan bahwa dan IOS berpengaruh positif pada return saham.

Melihat research gap dan fenomena yang terjadi pada Tabel 1.1 memotivasi penulis untuk mengadakan penelitian mengenai faktor-faktor yang mempengaruhi investment opportunity set (IOS) dan implikasinya terhadap return saham sebagai dampak dari adanya peluang investasi pada perusahaan Properti dan Real Estate yang terdaftar di BEI. Hal ini dikarenakan return saham atau keuntungan pengembalian merupakan salah satu faktor yang dipertimbangkan dalam pengambilan keputusan investasi dan motivasi para investor untuk melakukan investasi pada suatu instrumen yang diminati dengan harapan memperoleh tingkat pengembalian atau return investasi yang sesuai. Penelitian ini menggunakan pendekatan fundamental untuk mengetahui pengaruh investment opportunity set terhadap return saham.

\section{KAJIAN LITERATUR}

Teori trade-off dari struktur modal menunjukkan bahwa hutang bermanfaat bagi perusahaan karena bunga dapat dikurangkan dalam menghitung pajak (tax deductible), tetapi hutang juga menimbulkan biaya yang berhubungan dengan kebangkrutan yang aktual dan potensial. Struktur modal yang optimal berada pada keseimbangan antara manfaat pajak dari hutang dan biaya yang berkaitan dengan kebangkrutan. Hal ini disebut juga dengan balance theory, dimana perusahaan berupaya mempertahankan 
struktur modal yang optimal dengan tujuan memaksimalkan nilai perusahaan. Trade off theory sebagai penyeimbang manfaat dan pengorbanan yang timbul sebagai akibat penggunaan hutang. Sejauh manfaat lebih besar, hutang akan ditambah. Tetapi apabila pengorbanan karena menggunakan hutang sudah lebih besar, maka hutang tidak boleh lagi ditambah (Husnan, 2010:324).

\section{- $\quad$ Return Saham}

Saham pada dasarnya merupakan bukti penyertaan modal dari investor kepada emiten yang menunjang bukti kepemilikan suatu perusahaan dan investor memiliki klaim atas penghasilan dan aktiva yang dimiliki perusahaan. Seperti yang diungkapkan oleh Darmadji et. al. (2012:5), saham (stock) didefinisikan sebagai tanda penyertaan atau pemilikan seseorang atau badan dalam suatu perusahaan atau perseroan terbatas. Saham berwujud selembar kertas yang menerangkan bahwa pemilik kertas tersebut adalah pemilik perusahaan yang menerbitkan surat berharga tersebut.

Return merupakan salah satu faktor yang memotivasi investor berinvestasi dan juga merupakan imbalan atas keberanian investor menanggung resiko atas investasi yang dilakukannya. (Tandelilin,2014:102). Sedangkan Brigham (2014:215) berpendapat return saham atau tingkat pengembalian saham adalah selisih antara jumlah yang diterima dan jumlah yang diinvestasikan, dibagi dengan jumlah yang diinvestasikan. Selanjutnya Fahmi (2014:152) mengemukakan bahwa return saham adalah keuntungan yang diharapkan oleh seorang investor di kemudian hari terhadap sejumlah dana yang telah ditempatkannya. Pengharapan menggambarkan sesuatu yang bisa saja terjadi diluar dari yang diharapkan.

\section{- Investment Opportunity Set (IOS)}

Investasi merupakan suatu aktiva yang digunakan perusahaan untuk pertumbuhan kekayaan di masa yang akan datang. Setiap perusahaan yang melakukan investasi baru dalam aktiva tetap selalu dengan harapan bahwa perusahaan akan memperoleh kembali dana yang tertanam dalam investasi. Perusahaan akan melakukan investasi berdasarkan pada peluang investasi dan modal yang mencukupi.

Hartono (2016:58) mengatakan kesempatan investasi atau Invesment Opportunity Set (IOS) menggambarkan tentang luasnya kesempatan atau peluang investasi bagi suatu perusahaan. Sedangkan Sunariyah (2011:56) berpendapat Set Kesempatan Investasi adalah kombinasi antara aktiva yang dimiliki perusahaan (assets 
in place) dan pemilihan investasi pada masa yang akan datang dengan net present value (NPV) yang positif.

\section{- Struktur Modal}

Struktur modal merupakan bauran pendanaan hutang jangka panjang dan ekuitas (Brealey et al.,2011:600). Struktur modal merupakan perimbangan jumlah utang jangka pendek yang bersifat permanen, utang jangka panjang, saham prefern dan saham biasa (Sartono,2014:225). Definisi lain dari struktur modal merupakan gambaran dari bentuk proporsi finansial perusahaan yaitu antara modal yang dimiliki yang bersumber dari utang jangka panjang (long-term liabilities) dan modal sendiri (shareholders' equity) yang menjadi sumber pembiayaan suatu perusahaan (Fahmi,2014:184).

\section{- Pertumbuhan Penjualan}

Pertumbuhan perusahaan yang tinggi mencerminkan semakin luasnya jangkauan perusahaan. Pertumbuhan perusahaan yang tinggi menunjukkan kinerja perusahaan yang baik, karena terjadi peningkatan terhadap aset atau penjualan perusahaan. Pertumbuhan juga menggambarkan kemampuan perusahaan dalam mempertahankan eksistensinya dalam sektor usaha yang dijalankan. Seperti yang diungkapkan oleh Fahmi (2014:82), pertumbuhan merupakan rasio yang mengukur seberapa besar kemampuan perusahaan dalam mempertahankan posisinya di dalam industri dan dalam perkembangan ekonomi secara umum. Rasio pertumbuhan ini dilihat dari berbagai segi sales (penjualan), earning after tax (EAT), laba per lembar saham, dividen perlembar saham, dan harga pasar perlembar saham. Selanjutnya Ross, et. al. (2015:121) juga menyatakan bahwa Pertumbuhan semata-mata merupakan alat yang sesuai untuk memeriksa antara keputusan investasi dan pendanaan.

\section{- Ukuran Perusahaan}

Riyanto (2013:313) menjelaskan ukuran perusahan adalah besar kecilnya perusahaan dilihat dari besarnya nilai equity, nilai penjualan atau nilai aktiva. Perusahaan besar yang sudah well-established akan lebih mudah memperoleh modal di pasar modal dibanding dengan perusahaan kecil. Karena kemudahan akses tersebut berarti perusahaan besar memiliki fleksibilitas yang lebih besar pula (Sartono,2014:249). Karena perusahaan yang besar cenderung memiliki sumber permodalan yang lebih banyak dan memiliki kemungkinan untuk bangkrut yang lebih kecil, sehingga lebih mampu untuk memenuhi kewajiban finansialnya. Dengan kata 
lain, perusahaan besar cenderung memiliki utang atau menggunakan dana eksternal dalam jumlah yang lebih besar.

\section{- $\quad$ Kinerja Perusahaan}

Kinerja keuangan merupakan gambaran dari rangkaian pencapaian perusahaan dan aktivitas keuangan perusahaan dalam suatu periode yang disajikan dalam bentuk laporan keuangan. Hal ini serupa dengan yang di sampaikan oleh Fahmi (2014:2) yang menyatakan bahwa kinerja keuangan adalah suatu analisis yang dilakukan untuk melihat sejauh mana suatu perusahaan telah melaksanakan dengan menggunakan aturan-aturan pelaksanaan keuangan secara baik dan benar. Kinerja perusahaan merupakan suatu gambaran tentang kondisi keuangan suatu perusahaan yang dianalisis dengan alat-alat analisis keuangan, sehingga dapat diketahui mengenai baik buruknya keadaan keuangan suatu perusahaan yang mencerminkan prestasi kerja dalam periode tertentu. Setiap laporan keuangan yang dibentuk untuk menampilkan kinerja keuangan memiliki tujuan yang ingin dicapai oleh masing-masing perusahaan. Analisa rasio keuangan menurut Munawir (2015:106), adalah future oriented atau berorientasi pada dengan masa depan, artinya bahwa dengan analisa 10 ratio keuangan dapat digunakan sebagai alat untuk meramalkan keadaan keuangan serta hasil usaha dimasa yang akan dating. Dengan angka-angka rasio historis atau kalau memungkinkan dengan angka rasio industri (yang dilengkapi dengan angka rasio industri yang dilengkapi dengan data lainnya) dapat digunakan sebagai dasar untuk penyusunan laporan keuangan yang diproyeksikan yang merupakan salah satu bentuk perencanaan keuangan perusahaan.

Menurut Hanafi (2016:74), Rasio keuangan dikelompokkan dalam lima jenis yaitu:

1) Rasio likuiditas, yaitu rasio yang mengukur kemampuan perusahaan memenuhi kewajiban jangka pendeknya

2) Rasio aktivitas, yaitu rasio yang mengukur sejauh mana efektivitas penggunaan aset dengan melihat aktivitas aset

3) Rasio solvabilitas, yaitu rasio yang mengukur sejauh mana kemampuan perusahaan memenuhi kebutuhan jangka panjangnya

4) Rasio profitabilitas, yaitu rasio yang melihat kemampuan perusahaan menghasilkan laba (profitabilitas) 
5) Rasio pasar, yaitu rasio ini melihat perkembangan nilai perusahaan relatif terhadap nilai buku perusahaan.

Dalam penelitian ini analisis rasio keuangan pertama yang digunakan adalah rasio profitabilitas. Fahmi (2014:239) berpendapat profitabilitas adalah rasio yang menggambarkan kemampuan perusahaan untuk mampu menghasilkan keuntungan (profit). Semakin baik rasio profitabilitas maka semakin baik menggambarkan kemampuan tingginya perolehan keuntungan perusahaan.

Analisis rasio keuangan kedua adalah rasio likuiditas, Seperti yang diungkapkan Prastowo (2011:83), rasio Likuditas perusahaan menggambarkan kemampuan perusahaan dalam memenuhi kewajiban jangka pendeknya kepada kreditor jangka pendek. Perhitungan likuiditas cukup memberikan manfaat bagi berbagai pihak yang berkepentingan terhadap perusahaan. Pihak yang paling berkepentingan adalah pemilik perusahaan dan manajemen perusahaan untuk menilai kinerja perusahaannya. Ada pihak luar juga memiliki kepentingan, seperti pihak kreditor atau penyedia dana bagi perusahaan, misalnya perbankan atau juga distributor maupun supplier. Oleh karena itu, perhitungan likuiditas tidak hanya berguna bagi perusahaan, namun juga bagi pihak luar perusahaan.

\section{METODE PENELITIAN}

\section{A. Data dan Sampel}

Penelitian ini dilakukan pada perusahaan Properti dan Real Estate yang terdaftar di Bursa Efek Indonesia, sedangkan objek penelitian ini adalah struktur modal, pertumbuhan penjualan, ukuran perusahaan, profitabilitas, likuiditas, Investment Opportunity Set, dan return saham perusahaan tersebut dalam periode tahun 2013-2017. Data yang digunakan adalah data sekunder. Teknik pengumpulan data menggunakan teknik dokumentasi dengan mengumpulkan data sekunder dari laporan tahunan perusahaan dan histori data saham. Laporan tahunan di ambil dari website resmi Bursa Efek Indonesi dan data histori saham di ambil dari website resmi Yahoo Finance. Sampel menggunakan teknik purposive sampling. Penelitian ini menggunakan data panel dan untuk intervening test menggunakan Structural Equation Model (SEM). 


\section{B. Operasionalisasi Variabel}

- Struktur modal

Struktur modal adalah perimbangan atau perbandingan antara jumlah hutang jangka jangka panjang dengan modal sendiri.

- Sales Growth

Pertumbuhan penjualan menunjukan sejauh mana perusahaan dapat meningkatkan penjualannya dibandingkan dengan total penjualan secara keseluruhan.

- Ukuran Perusahaan

Ukuran perusahan adalah besar kecilnya perusahaan dilihat dari besarnya nilai equity, nilai penjualan atau nilai aktiva.

- Profitabilitas

Profitabilitas merupakan rasio yang menggambarkan kinerja fundamental perusahaan ditinjau dari tingkat efisiensi dan efektivitas operasi perusahaan dalam memperoleh laba.

- Likuiditas

Rasio Likuditas perusahaan menggambarkan kemampuan perusahaan dalam memenuhi kewajiban jangka pendeknya kepada kreditor jangka pendek.

- Investment Opportunity Set

Kesempatan Investasi adalah kombinasi antara aktiva yang dimiliki perusahaan (assets in place) dan pemilihan investasi pada masa yang akan datang dengan net present value (NPV) yang positif.

\section{Model Penelitian}

1. Model Persamaan I

$\mathrm{IOS}=\alpha+\beta \mathrm{LTD}_{i t}+\beta$ Sales $_{i t}+\beta$ Size $_{i t}+\beta \mathrm{ROE}_{i t}+\beta \mathrm{CR}_{i t}+e_{1}$

2. Model Persamaan II

Return $=\alpha+\beta \operatorname{IOS}_{i t}+\mathrm{e}$

3. Model Persamaan III

$\mathrm{IOS}=\alpha+\beta \mathrm{LTD}_{i t}+\beta$ Sales $_{i t}+\beta$ Size $_{i t}+\beta \mathrm{ROE}_{i t}+\beta \mathrm{CR}_{i t}+e_{1}$

4. Model Persamaan IV

Return $=\alpha+\beta \operatorname{IOS}_{i t}+\beta \mathrm{LTD}_{i t}+\beta$ Sales $_{i t}+\beta$ Size $_{i t}+\beta \mathrm{ROE}_{i t}+\beta \mathrm{CR}_{i t}+$ $e_{2}$ 


\section{HASIL PENELITIAN DAN PEMABAHASAN}

\subsection{Hasil dan Pembahasan Hipotesis}

\section{- Pengaruh Struktur Modal Terhadap Investment Opportunity Set $\left(\mathrm{H}_{1}\right)$}

Hasil perhitungan data untuk hipotesis pertama yang menguji pengaruh struktur modal pada investment opportunity set menunjukkan nilai $\mathrm{z}$ sebesar 1,24 (sig pada $\alpha=$ 5\%). Nilai signifikansi dari struktur modal adalah 0,214 (di atas 0,05), sehingga dapat disimpulkan bahwa struktur modal tidak mempengaruhi investment opportunity set, ini berarti bahwa hipotesis pertama ditolak.

Hasil penelitian ini menunjukkan bahwa struktur modal tidak memiliki pengaruh pada investment opportunity set. Berdasarkan Trade off theory perusahaan harus menyeimbangkan antara manfaat menggunakan hutang dan biaya yang ditimbulkan dari penggunaan hutang untuk mencapai struktur modal optimal. Walaupun perusahaan yang mempunyai kesempatan investasi yang tinggi membutuhkan dana yang tinggi, dimana tidak cukup jika hanya didanai dari internal perusahaan, namun apabila perusahaan sudah menetapkan struktur modal yang optimal hal ini tidak akan berpengaruh terhadap set kesempatan investasi.

Hasil ini tidak sesuai dengan penelitian yang dilakukan oleh Pramiana,dkk (2015) yang menyatakan struktur modal perusahaan mempengaruhi investment opportunity set.

\section{- Pengaruh Pertumbuhan Penjualan Terhadap Terhadap Investment Opportunity}

Set. $\left(\mathrm{H}_{2}\right)$

Hasil perhitungan data untuk hipotesis kedua yang menguji pengaruh pertumbuhan penjualan pada investment opportunity set menunjukkan nilai z sebesar 1,24 (sig pada $\alpha=5 \%$ ). Nilai signifikansi dari pertumbuhan penjualan adalah 0,217 (di atas 0,05), sehingga dapat disimpulkan bahwa pertumbuhan penjualan tidak mempengaruhi investment opportunity set, ini berarti bahwa hipotesis kedua ditolak.

Hasil penelitian ini menunjukkan bahwa pertumbuhan penjualan tidak memiliki pengaruh pada investment opportunity set. Perusahaan dengan pertumbuhan penjualan yang tinggi belum tentu memiliki investment opportunity set yang tinggi. Hal ini, disebabkan pertumbuhan penjualan tidak menjadi pertimbangan utama manajemen dalam menentukan keputusan berinvestasi yang akan dilakukan. Pertumbuhan penjualan 
mungkin dinilai sebagai sinyal adanya pertumbuhan pada perusahaan tersebut namun tidak menjadi penjamin bahwa perusahaan tersebut memiliki kesempatan investasi yang tinggi. Hal ini di gambarkan dengan nilai koefisien pertumbuhan penjualan yang bernilai negatif dimana keadaan ini menggambarkan bahwa pertumbuhan penjualan memiliki pengaruh negatif terhadap investment opportunity set walaupun tidak signifikan.

Namun, hasil ini tidak sesuai dengan penelitian yang dilakukan oleh Francis et al. (2013) yang mengatakan bahwa pertumbuhan mempengaruhi investment opportunity set.

- Pengaruh Ukuran Perusahaan Terhadap Terhadap Investment Opportunity Set. $\left(\mathrm{H}_{3}\right)$

Hasil perhitungan data untuk hipotesis ketiga yang menguji pengaruh ukuran perusahaan pada investment opportunity set menunjukkan nilai z sebesar -1,16 (sig pada $\alpha=5 \%$ ). Nilai signifikansi dari ukuran perusahaan adalah 0,246 (di atas 0,05), sehingga dapat disimpulkan bahwa ukuran perusahaan tidak mempengaruhi investment opportunity set, ini berarti bahwa hipotesis ketiga ditolak.

Hasil penelitian ini menunjukkan bahwa ukuran perusahaan tidak memiliki pengaruh pada investment opportunity set. Nilai koefisien bertanda negatif yang artinya ukuran perusahaan memiliki mempengaruhi negatif terhadap investment opportunity set, hal ini dikarenakan meskipun perusahaan besar dinilai mampu meningkatkan kesempatan investasi perusahaan dengan adanya aset dan pendanaan yang memadai, perusahaan besar cenderung stagnan dalam menanggapi kesempatan investasi. Perusahaan yang telah stabil (well-estabilshed) akan lebih mempertahankan penghasilan atau penjualan yang di perolehnya di banding harus mengambil kesempatan investasi yang belum tentu menguntungkan.

Hasil ini berbanding terbalik dengan yang disampaikan oleh Utama dan Meiti (2015) yang menyatakan bahwa ukuran perusahaan perusahaan mempengaruhi investment opportunity set.

\section{- Pengaruh Profitabilitas Terhadap Terhadap Investment Opportunity Set. $\left(\mathrm{H}_{4}\right)$}

Hasil perhitungan data untuk hipotesis keempat yang menguji pengaruh profitabilitas pada investment opportunity set menunjukkan nilai z sebesar 4,18 (sig pada $\alpha=5 \%$ ). Nilai signifikansi dari profitabilitas adalah 0,000 (di bawah 0,05), 
sehingga dapat disimpulkan bahwa profitabilitas mempengaruhi investment opportunity set, ini berarti bahwa hipotesis keempat diterima.

Hasil penelitian ini menunjukkan bahwa profitabilitas memiliki pengaruh pada investment opportunity set. Profitabilitas menunjukkan kemampuan perusahaan untuk menghasilkan laba, semakin besar kemampuan laba perusahaan, semakin besar kemungkinan laba ditahan untuk tujuan investasi. Perusahaan dengan profitabilitas tinggi mampu meningkatkan peluang pertumbuhan perusahaan jika perusahaan dapat menginvestasikan pendapatannya ke dalam proyek-proyek di mana ROE melebihi biaya modal. Karena hal ini, perusahaan akan mempertimbangkan kesempatan investasi yang ada guna memanfaatkan dana yang tersedia dari keuntungan perusahaan dengan harapan investasi yang dilakukan akan menambah keuntungan bagi perusahaan.

Hasil ini konsisten dengan penelitian sebelumnya pada Utama dan Meiti (2015) Namun, hasil ini tidak sesuai dengan penelitian yang dilakukan oleh Reni,dkk (2013) yang memberikan hasil bahwa profitabilitas perusahaan tidak mempengaruhi investment opportunity set.

\section{- Pengaruh Likuiditas Terhadap Terhadap Investment Opportunity Set. $\left(\mathrm{H}_{5}\right)$}

Hasil perhitungan data untuk hipotesis keslima yang menguji pengaruh likuiditas pada investment opportunity set menunjukkan nilai $\mathrm{z}$ sebesar $-2,73$ (sig pada $\alpha=$ 5\%). Nilai signifikansi dari likuiditas adalah 0,006 (di bawah 0,05), sehingga dapat disimpulkan bahwa likuiditas berpengaruh signifikan terhadap investment opportunity set, ini berarti bahwa hipotesis kelima diterima.

Hasil penelitian ini menunjukkan bahwa likuiditas memiliki pengaruh pada investment opportunity set. Kesempatan investasi dengan meningkatkan pemakaian dana untuk pembelian harta tetap adalah salah satu penyebab utama perusahaan menjadi tidak likuid, karena semakin banyak dana perusahaan digunakan untuk harta tetap maka sisanya untuk membiayai kebutuhan jangka pendek tinggal sedikit. Hal ini menggambarkan bahwa semakin tinggi kesempatan investasi perusahaan akan menurunkan likuidity perusahaan.

Hasil ini konsisten dengan penelitian sebelumnya seperti pada Gregoriu dan Nguyen (2010). Namun, hasil ini tidak sesuai dengan penelitian yang dilakukan oleh Yendrawati (2013) yang memberikan hasil bahwa likuiditas perusahaan tidak mempengaruhi investment opportunity set. 


\section{- Pengaruh Investment Opportunity Set Terhadap Return Saham. $\left(H_{6}\right)$}

Hasil perhitungan data untuk hipotesis keenam yang menguji pengaruh investment opportunity set pada return saham menunjukkan nilai z sebesar 2,16 (sig pada $\alpha=5 \%$ ). Nilai signifikansi dari investment opportunity set adalah 0,031 (di bawah 0,05), sehingga dapat disimpulkan bahwa investment opportunity set mempengaruhi return saham, ini berarti bahwa hipotesis keenam diterima.

Hasil penelitian ini menunjukkan bahwa investment opportunity set memiliki pengaruh pada return saham. Variabel investment opportunity set mempunyai pengaruh yang positif dan signifikan terhadap return saham yang berarti ada atau tidaknya kesempatan investasi akan berdampak langsung pada return saham. Perusahaan yang memiliki kesempatan investasi yang tinggi, akan memiliki prospek pertumbuhan ke depan yang cerah hal ini akan direspon pasar dan menarik minat investor dan akan berpengaruh pada peningkatan harga saham, sehingga return saham perusahaan akan meningkat.

Hasil ini konsisten dengan penelitian sebelumnya seperti pada Puteri,dkk (2012). Namun, hasil ini tidak sesuai dengan penelitian yang dilakukan oleh Herdyan (2017) yang memberikan hasil bahwa investment opportunity set tidak mempengaruhi return saham.

\section{- Investment Opportunity Set Memediasi Hubungan Antara Struktur Modal dan Return Saham.}

Hasil pengujian data untuk hipotesis ketujuh menunjukkan bahwa p1 $(0,214)$ dan p2 $(0,031)$ dalam penelitian langsung dan p3 $(0,038)$ dalam penelitian tidak langsung antara struktur modal dan return saham. Ini menunjukkan bahwa terdapat dua probabilitas yang memiliki efek yang signifikan, sehingga disimpulkan bahwa tingkat investment opportunity set merupakan variabel mediasi, ini berarti bahwa hipotesis ketujuh diterima.

Hal ini menunjukan, apabila struktur modal perusahaan semakin meningkat, investment opportunity set juga semakin besar maka akan menjadikan return saham menjadi naik.

Hasil penelitian ini menunjukkan bahwa investment opportunity set dapat memediasi hubungan antara struktur modal dan return saham. 


\section{- Investment Opportunity Set Memediasi Hubungan Antara Pertumbuhan} Penjualan dan Return Saham.

Hasil pengujian data untuk hipotesis kedelapan menunjukkan bahwa p1 $(0,217)$ dan p2 (0,031) dalam penelitian langsung dan p3 $(0,267)$ dalam penelitian tidak langsung antara pertumbuhan penjualan dan return saham. Ini menunjukkan bahwa satu probabilitas tidak memiliki efek langsung dan tidak signifikan, sehingga disimpulkan bahwa tingkat investment opportunity set bukan variabel mediasi, ini berarti bahwa hipotesis kedelapan ditolak.

Hal ini menunjukan, pertumbuhan perusahaan memiliki pengaruh negatif terhadap investment opportunity set namun tidak signifikan. Apabila pertumbuhan perusahaan semakin menurun, maka investment opportunity set akan semakin besar namun belum tentu akan menjadikan return saham menjadi naik. Hal ini dikarenakan pertumbuhan penjualan tidak menjadi jaminan akan mendapatkan tingkat pengembalian yang tinggi dan menjamin keamanan terhadap modal yang ditanamkan. Maka dari itu hasil penelitian ini menunjukkan bahwa investment opportunity set tidak dapat memediasi hubungan antara pertumbuhan penjualan dan return saham.

\section{- Investment Opportunity Set Memediasi Hubungan Antara Ukuran Perusahaan}

\section{dan Return Saham.}

Hasil pengujian data untuk hipotesis ketiga menunjukkan bahwa p1 $(0,246)$ dan p2 $(0,031)$ dalam penelitian langsung dan p3 $(0,103)$ dalam penelitian tidak langsung antara ukuran perusahaan dan return saham. Ini menunjukkan bahwa salah satu probabilitas tidak memiliki efek langsung dan tidak signifikan, sehingga disimpulkan bahwa tingkat investment opportunity set bukan variabel mediasi, ini berarti bahwa hipotesis kesembilan ditolak.

Hal ini menunjukan, apabila ukuran perusahaan berubah, dan investment opportunity set semakin besar, belum tentu akan menjadikan return saham menjadi naik. Karena walaupun perusahaan besar lebih terpandang oleh investor tahan krisis dan memiliki kepastian dalam memperoleh keuntungan sehingga perusahaan besar akan lebih mudah untuk memiliki kesempatan investasi namun perusahaan besar yang memperoleh pendapatan yang besar memiliki tingkat pertumbuhan yang kecil, hal ini dikarenakan pendapatan yang diperoleh pada tahun sebelumnya relatif sudah besar. Hal 
ini memungkinkan tingkat return saham perusahaan menjadi stagnan walaupun perusahaan tersebut memiliki kesempatan investasi yang positif.

Hasil penelitian ini menunjukkan bahwa investment opportunity set tidak dapat memediasi hubungan antara ukuran perusahaan dan return saham.

- Investment Opportunity Set Memediasi Hubungan Antara Profitabilitas dan Return Saham.

Hasil pengujian data untuk hipotesis keempat menunjukkan bahwa p1 $(0,000)$ dan p2 $(0,031)$ dalam penelitian langsung dan p3 $(0,020)$ dalam penelitian tidak langsung antara profitabilitas dan return saham. Ini menunjukkan bahwa semua probabilitas memiliki efek langsung dan signifikan, sehingga disimpulkan bahwa tingkat investment opportunity set merupakan variabel mediasi, ini berarti bahwa hipotesis kesepuluh diterima.

Hal ini menunjukan, apabila profitabilitas perusahaan semakin meningkat, maka investment opportunity set juga semakin besar maka akan menjadikan return saham menjadi naik.

Hasil penelitian ini menunjukkan bahwa investment opportunity set dapat memediasi hubungan antara profitabilitas dan return saham.

- Investment Opportunity Set Memediasi Hubungan Antara Likuiditas dan Return Saham.

Hasil pengujian data untuk hipotesis kelima menunjukkan bahwa p1 $(0,006)$ dan p2 $(0,031)$ dalam penelitian langsung dan p3 $(0,135)$ dalam penelitian tidak langsung antara likuiditas dan return saham. Ini menunjukkan bahwa salah satu probabilitas tidak memiliki tidak signifikan, sehingga disimpulkan bahwa tingkat investment opportunity set bukan variabel mediasi, ini berarti bahwa hipotesis kesebelas ditolak.

Hal ini menunjukan, penuruan likuiditas perusahaan akibat adanya peningkatan investment opportunity set tidak berpengaruh sgnifikan terhadap return saham. Hal ini dikarenakan nilai Current Ratio (CR) memiliki kelemahan yaitu Current Ratio (CR) dapat menjadi window dressing oleh pihak manajemen. Manajemen dapat melakukan langkah-langkah tertentu untuk membuat neraca tampak baik sehingga menghasilkan nilai $\mathrm{CR}$ yang baik walaupun nilai $\mathrm{CR}$ telah menurun akibat adanya kesempatan investasi. Dengan adanya kemungkinan ini, investor mungkin saja berhati-hati dalam memilih rasio apa saja yang akan menjadi pertimbangan sehingga ada kemungkinan 
investor tidak memasukkan CR dalam pertimbangannya. Bila demikian, maka CR tidak akan berpengaruh terhadap keputusan investor dan tidak akan mempengaruhi retrun saham.

Hasil penelitian ini menunjukkan bahwa investment opportunity set tidak dapat memediasi hubungan antara likuiditas dan return saham.

\section{SIMPULAN DAN SARAN}

Berdasarkan tes, proses dan analisis yang telah dilakukan maka yang dapat disimpulkan dalam penelitian ini adalah struktur modal, pertumbuhan penjualan dan ukuran perusahaan tidak memiliki pengaruh terhadap investment opportunity set, sedangkan profitabilitas dan likuiditas memiliki pengaruh terhadap investment opportunity set. Investment opportunity set memiliki pengaruh pada return saham. Dan faktor-faktor yang mempengaruhi investment opportunity set mampu meningkatkan pengaruh investment opportunity set terhadap return saham.

Bagi peneliti lebih lanjut disarankan untuk menambah variabel lain yang mempengaruhi return saham dalam melakukan analisis, hal ini disebabkan karena temuan penelitian menunjukan rendahnya variasi return saham yang berarti ada faktor lain yang mungkin masuk dalam penelitian ini. Seperti meneliti rasio lain sebagai pengukur kinerja perusahaan, misalnya Earning per share (EPS) yang sering digunakan investor untuk menganalisi kemampuan perusahaan mencetak laba berdasarkan saham yang dimiliki, dan faktor-faktor makro ekonomi seperti nilai tukar mata uang yang dapat mempengaruhi investor dalam mengambil keputusan investasi. Selain itu sebaiknya peneliti lainnya juga melakukan pengambilan sampel yang lebih banyak dan waktu periode penelitian yang lebih lagi agar memberikan hasil yang lebih baik.

Perusahaan properti dan real estate dapat mempertimbangkan dan memperhatikan ketersediaan kesempatan investasi bagi perusahaan, karena temuan menunjukan bahwa investment opportunity set berpengaruh positif baik terhadap return saham dan di tambah lagi faktor-faktor yang mempengaruhi investment opportunity set dalam penelitian ini faktor struktur modal dan profitabilitas juga memiliki pengaruh signifikan dalam hubungan antara investment opportunity set dan return saham pada perusahaan properti dan real estate yang terdaftar di Bursa Efek Indonesia.

Selanjutnya para investor dapat mempertimbangkan dan memperhatikan ketersediaan investment opportunity set, struktur modal dan profitabilitas dalam 
pengambilan keputusan investasi yang akan dilakukan pada perusahaan properti dan real estate.

\section{DAFTAR PUSTAKA}

Acaravci, Songul Kakilli. 2015. The Determinants of Capital Structure: Evidence from the Turkish Manufacturing Sector. International Journal of Economics and Financial Issues Vol. 5, No. 1, 2015, pp.158-171

Adiwibowo, Akhmad Sigit. 2018. Pengaruh Manajemen Laba, Ukuran Perusahaan \& Leverage Terhadap Return Saham dengan Kebijakan Dividen Sebagai Variabel Moderasi. Jurnal Ilmiah Akuntansi Universitas Pamulang vol. 6, No. 2, Juli 2018. Aisah, Ayu Nurhayani \& Kastawan Mandala. 2016. Pengaruh Return On Equity, Earning Per Share, Firm Size \& Operating Cash Flowterhadap Return Saham. EJurnal Manajemen Unud, Vol. 5, No. 11, 2016: 6907-6936 ISSN : 2302-8912

Andriasari, Widi Savitri, Miyasto \& Wisnu Mawardi. 2016. Analisis Pengaruh Kebijakan Hutang, Pertumbuhan Penjualan (Growth Sales) Dan Return On Asset (ROA) Terhadap Return Saham Dengan Return On Equity (ROE) Sebagai Variabel Intervening (Studi pada Perusahaan Manufaktur yang Terdaftar di BEI Tahun 2010 - 2014). Jurnal Bisnis STRATEGI Vol. 25 No. 2 Juli 2016. Hal 135151.

Ang, R. 1997. Buku Pintar Pasar Modal Indonesia. Jakarta: Mediasof.

Ashari, Dwi Putranto \& Ari Darmawan. 2018. Pengaruh Ukuran Perusahaan, Profitabilitas, Leverage, \& Nilai Pasar Terhadap Harga Saham (Studi Kasus Pada Perusahaan Pertambangan Yang Terdaftar Di Bursa Efek Indonesia Periode 20102016). Jurnal Administrasi Bisnis (Jab) Vol. 56 No. 1 Maret 2018. Administrasibisnis.Studentjournal.Ub.Ac.Id [05/05/19]

Asri, I Gusti Ayu, Amanda Yulita \& I Ketut Suwarta. 2014. Pengaruh Faktor Fundamental \& Ekonomi Makro Pada Return Saham Perusahaan Consumer Good. ISSN: 2302-8556 E-Jurnal Akuntansi Universitas Udayana.8.3 (2014):353370

Astuti, Ade Pendria \& Yulia Efni. 2015. Pengaruh Kesempatan Investasi, Leverage Terhadap Kebijakan Deviden Dan Nilai Perusahaan Pada Perusahaan Manufaktur Yang Terdaftar Di Bursa Efek Indonesia. Jurnal Tepak Manajemen Bisnis. Vol. VII No. 3 September 2015 Hal 343 - 356 
Bella, Luh Kadek Githa \& I.G.N. Agung Suaryana. 2017. Pengaruh IOS Dan Pengungkapan CSR Pada Nilai Perusahaan Dengan Pertumbuhan Perusahaan Sebagai Variabel Pemoderasi. ISSN: 2302-8556 E-Jurnal Akuntansi Universitas Udayana. Vol.19.1. April (2017): 508-535

Bintara, Rista. 2018. Pengaruh Profitabilitas, Growth Opportunity, Dan Struktur Modal Terhadap Nilai Perusahaan Dengan Good Corporate Governance Sebagai Variabel Pemoderasi. Profita: Komunikasi Ilmiah Akuntansi dan Perpajakan PISSN: 2086-7662 Vol. 11 No. 2 | Agustus 2018

Brealey, Myers, \& Marcus. 2011. Dasar-Dasar Manajemen Keuangan Perusahaan. Jakarta: Erlangga.

Brigham, E.F \& Houston, J.F. 2014. Dasar-Dasar Manajemen Keuangan. Jakarta: Salemba Empat.

Darmadji, Tjiptono \& Fakhruddin. 2012. Pasar Modal di Indonesia, edisi 3. Jakarta : Salemba Empat, Jakarta

Erosvitha, Cicilia Kadek Lia \& Ni Gusti Putu Wirawati. 2016. Pengaruh Profitabilitas,

Set Kesempatan Investasi, Pertumbuhan Penjualan Dan Risiko Bisnis Pada Struktur Modal. ISSN: 2303-1018 E-Jurnal Akuntansi Universitas Udayana Vol. 14.1 Januari 2016: 172-197

Erlina. 2011. Metodologi Penelitian : Untuk Akuntansi, Medan : USU PRESS.

Fahmi, Irham. 2014. Analisis Laporan Keuangan. Bandung : Alfabeta.

Febrioni, Rio. 2016. Pengaruh Return On Assets, Return On Equity, Earning Per Share, \& Current Ratio Terhadap Return Saham (Pada Perusahaan Yang Terdaftar Di Indeks Lq45 Di Bursa Efek Indonesia Tahun 2011-2015). ISSN : 2355-9357 EProceeding Of Management : Vol.3, No.3 December 2016, Page 3439.

Francis, B., I. Hasan, L. Song, And M. Waisman. 2013. Corporate Governance And Investment Cash-Flow Sensitivity: Evidence From Emerging Markets. Emerging Markets Review 15: 57-71.

Ghozali, Imam. 2012. Aplikasi Analisis Multivariate Dengan Program IBM SPSS 20. Semarang : UNDIP.

Gregoriu, Andros \& Nguyen Ngoc Dung. 2010. Stock Liquidity And Investment Opportunities: New Evidence From Ftse 100 Index Deletions. Journal Of 
International Financial Markets, Institutions And Money, Vol 20(3), Pages 267274, July.

Hanafi, Mamduh M. 2016. Manajemen Keuangan. Edisi kedua, Cetakan pertama. Yogyakarta: BPFE

Hanafi, Mamduh \& Halim, Abdul. 2012. Analisis Laporan Keuangan. Edisi Ketiga. Cetakan Pertama. Yogyakarta : Penerbit UPP Sekolah Tinggi Ilmu Manajemen YKPN.

Harmono. 2014. Manajemen Keuangan: Berbasis Balanced Scorecard, Edisi Pertama, Jakarta : Bumi Aksara.

Hartono, Jogiyanto.2016. Teori Portofolio dan Analisis Investasi, Edisi Ke 10, Yogyakarta : BPFE

Herdyan, Dwiki. Norita, \& Dedik Nur Triyanto. 2017. Pengaruh Investment Opportunity Set, Kebijakan Dividen, Dan Keputusan Pendanaan Terhadap Return Saham. e-Proceeding of Management : Vol.4, No.2 Agustus 2017 | Page 1657

Hidayah, Nurul. 2015. Pengaruh Investment Opportunity Set (Ios) Dan Kepemilikan Manajerial Terhadap Nilai Perusahaan Pada Perusahaan Property Dan Real Estat Di Bursa Efek Indonesia. Jurnal Akuntansi/Volume XIX, No. 03, September 2015: 420-432

Horne, James C. Van \& John M. Wachowicz, Jr. 2012. Primsip-Prinsip Manajemen Keuangan (Fundamentals Of Financial Management). Edisi 13 Buku 1. Jakarta: Salemba Empat

Husnan, Suad. 2010. Manajemen Keuangan Teori \& Penerapan (Keputusan Jangka Panjang). Edisi Keempat. Yogyakarta : BPFE.

Husnan, Suad. 2015. Dasar-Dasar Teori Portofolio \& Analisis Sekuritas. (Edisi 5). Yogyakarta : UPPN STIM YKPN.

Indriantoro, Nur \& Supomo, Bambang. 2014. Metodologi Penelitian Bisnis Untuk Akuntansi dan Manajemen. Yogyakarta : BPFE-Yogyakarta

Jannati T., Mahfudnurnajamuddin, Masdar Mas'ud, Lukman Chalid. 2018. Investment opportunity set: evidence from Indonesian Banking. International Journal of Business and Management Invention. Volume 3 Issue 9 || September. 2014 || PP.41-46 . ISSN (Online): 2319 - 8028.

www.ijbmi.org Volume 3 Issue 9 || September. 2014 || PP.41-46 
Kallapur, S., \& Trombley, M.K. 2001. The Investment Opportunity Set:

Determinants, Consequences, And Measurement, Managerial Finance 27.Pp. 3-15.

Kariuki, Samuel Nduati \& Charles Guandaru Kamau. 2014. Determinants of Corporate Capital Structure among Private Manufacturing Firms in Kenya: A Survey of Food and Beverage Manufacturing Firms. International Journal of Academic Research in Accounting, Finance and Management Sciences. Vol. 4, No.3, July 2014, pp. 49-62

Kasmir. 2016. Analisis Laporan Keuangan. Jakarta : PT. Raja Grafindo Persada.

Kaestner, R., dan F. Y. Liu, 1998, New Evidence on The Information Content of Dividend Announcement. The Quarterly Review of Economics and Finance.Vol. 38. [2]: 251-274.

Hendijani, Iman Abadi. 2014. A Study Of The Correlation Between Investment

Opportunities And Current Assets Growth In Firms Listed In Tehran Stock Exchange Iran. Iran: Islamic Azad University. Research Journal Of Recent Sciences Vol. 3(3), 65-71, March (2014) ISSN 2277-2502

Handrian, Eka \& Robiyanto Robiyanto. 2018. Investment Opportunity And Industrial

Growth In Indonesia. International Journal of Business and Society, Vol. 19 No. 2, 2018, 295-312.

Handiani, Eka \& Tjiptowati Endang Irianti. 2015. Investment Opportunity Set berbasis

Pertumbuhan Perusahaan dan Kaitannya dengan Upaya Peningkatan Nilai

Perusahaan. Jurnal Ekonomi dan Bisnis. Voluem XVIII No.1 , April 2015 P 83-99 Herdyan, Dwiki, Norita \& Dedik Nur Triyanto. 2017. Pengaruh Investment Opportunity

Set, Kebijakan Dividen, Dan Keputusan Pendanaan Terhadap Return Saham. eProceeding of Management : Vol.4, No.2 Agustus 2017 | Page 1657-1665.

Hery. 2016. Analisis Laporan Keuangan. Jakarta: Grasindo.

Manik, Tumpal. 2014. Analisis Pengaruh Struktur Modal Dan Investment Opportunity Set (IOS) Terhadap Keputusan Investasi Dan Harga Saham Melalui Analisis Jalur. Seminar Nasional dan Call for Papers Dies Natalis UNS XXXVIII Fakultas Ekonomi dan Bisnis Universitas Sebelas Maret Surakarta 18-19 Maret 2014.

Margaretha, Farah. 2011. Teori \& Aplikasi Manajemen Keuangan Investasi \& Sumber dana Jangka Pendek. Jakarta: Grasindo Gramedia Widiasarana Indonesia. 
Mateos-Ronco, Alicia \& Sandra Guzmán-Asunción. 2018. Determinants of financing decisions and management implications: evidence from Spanish agricultural cooperatives. International Food and Agribusiness Management Review Volume 21 Issue 6, 2018.

Milka M. Oroh, Paulina Van Rate, \& Christoffel Kojo. 2019. Pengaruh Profitabilitas Dan Leverage Terhadap Return Saham Pada Sektor Pertanian Di Bei Periode 2013-2017. Jurnal EMBA Vol.7 No.1 Januari 2019, Hal. 661 - 670.

Munawir, S. 2015. Analisis Laporan Keuangan. Jakarta: Salemba Empat Myers, Stewart C. 1977. Determinant Of Corporate Borrowing, Journal Of Financial Economics 5. Pp. 147-175.

Nurmasari, Ifa. 2017. Analisis Current Ratio, Return On Equity, Debt To Equity Ratio, Dan Pertumbuhan Pendapatan Berpengaruh Terhadap Return Saham Pada Perusahaan Pertambangan Di Bursa Efek Indonesia 2010-2014. Jurnal KREATIF : Pemasaran, Sumberdaya Manusia dan Keuangan, Vol. 5, No.1, Oktober 2017, Hal. 112-131

Pramiana, Omi, Dhani Ichsanuddin \& Diah Hari S. 2015. Investment Opportunity Set (IOS) Sektor Perbankan Di Bursa Efek Indonesia. ejournal.stiedewantara.ac.id . Vol X No 2, Oktober 2015, Hal. 118 -135

Prastowo, Dwi. 2015. Analisis Laporan Keuangan Konsep \& Aplikasi. Yogyakarta: STIM YKPN.

Purwitajati, Endah \& I Made Pande Dwiana Putra. 2016. Pengaruh Debt To Equity Ratio Pada Return Saham Dengan Ukuran Perusahaan Sebagai Pemoderasi. ISSN: 2302-8556. E-Jurnal Akuntansi Universitas Udayana Vol.15.2. Mei (2016): 10861114

Putra, I Made Gunartha Dwi \& I Made Dana. 2016. Pengaruh Profitabilitas, Leverage, Likuiditas \& Ukuran Perusahaan Terhadap Return Saham Perusahaan Farmasi Di Bei. E-Jurnal Manajemen Unud, Vol. 5, No. 11, 2016: 6825-6850 ISSN : 23028912

Puteri, Paramitha Anggia \& Rohman, Abdul. 2012. Analisis Pengaruh Investment Opportunity Set (IOS) dan Mekanisme Corporate Governance Terhadap Kualitas Laba Dan Nilai Perusahaan. Diponegoro Journal Of Accounting, Volume 1, Nomor 2. 
Raningsih, Ni Kadek \& I Made Pande Dwiana Putra. 2015. Pengaruh Rasio-Rasio Keuangan \& Ukuran Perusahaan Pada Return Saham. ISSN: 2302-8556 E-Jurnal Akuntansi Universitas Udayana Vol.13.No.2 Nov. 2015. (Hal 582-598)

Rashid, Ameer. 2014. Financial constraints and corporate investment in Asian countries. Journal of Asian Economics, 33, p 44-55.

Riyanto, Bambang. 2013. Dasar-Dasar Pembelanjaan Perusahaan. Yogyakarta : BPFE.

Ross, Stephen A.; Randolph W. Westerfield; Bradford D. Jordan, Joseh Lim dan Ruth Tan. 2015. Pengantar Keuangan Perusahaan (Fundamentals of Corporate Finance). Edisi Global Asia, Buku 1. Jakarta: Salemba Empat

Safitri, Norma \& Aniek Wahyuati. 2015. Pengaruh struktur modal dan keputusan investasi terhadap profitabilitas dan nilai perusahaan. Jurnal Ilmu dan Riset Manajemen Volume 4, Nomor 2.

Saifi, Muhammad, Suhadak, Sri Mangesti Rahayu \& Siti Ragil Handayani. 2015. The Effect of Corporate Governance and Investment Opportunity Set on Capital Structure, Dividend Policy, and Firm Performance (A Study on Go-Public Manufacturing Companies in Indonesia Stock Exchange). International Journal of Management and Administrative Sciences (IJMAS) (ISSN: 2225-7225) Vol. 3, No. 02, (53-63)

Samsul, Mohamad. 2015. Pasar Modal \& Manajemen Portofolio, Edisi 2, Jakarta : Erlangga.

Sanusi, Anwar. 2014. Metode Penelitian Bisnis. Jakarta : Salemba Empat.

Sartono, Agus. 2014. Manajemen Keuangan Teori \& Aplikasi, Yogyakarta : BPFE.

Sawir, Agnes . 2012. Analisis Kinerja Keuangan \& Perencanaan Keuangan Perusahaan. Jakarta: Gramedia Pustaka Utama.

Sholihin, M. dan D. Ratmono. 2013). Analisis SEM-PLS dengan WarpPLS 3.0 untuk Hubungan Nonlinier dalam Penelitian Sosial dan Bisnis. Yogyakarta : Andi.

Smith, Jr. W Clifford, \& Watts, R. L. 1992. The Investment Opportunity Set

And Corporate Financing, Dividend And Compensation Policies, Journal Of Financing Economics Vol. 32. PP. 263-292.

Soleman, Rusman. 2008. Karakteristik Perusahaan Terhadap Tingkat Leverage. Jurnal Keuangan \& Perbankan, Volume 12 No 3, Hal. 411-420 
Sudana, I Made. 2011. Manajemen Keuangan Perusahaan Teori dan Praktik. Jakarta: Erlangga

Sugiyono. 2013. Metode Penelitian Pendidikan Pendekatan Kuantitatif, Kualitatif, dan R\&D. Bandung: Alfabeta.

Sunariyah. 2013. Pengantar Pengetahuan Pasar Modal Edisi 2011. Yogyakarta : UPP AMP YPKN

Tandelilin, Eduardus. 2014. Portofolio dan Investasi. Yogyakarta : Kanisius

Utama, Cynthia A. \& Meiti Sulistika. 2015. Determinants Of Investment Opportunity Set (Degree Of Internationalization And Macroeconomic Variables). Gadjah Mada International Journal Of Business, Vol. 17, No. 2 (Mei-Agustus 2015): 107124.

www.idx.co.id

Yendrawati, Reni \& Feby Rezki Adhianza. 2013. Faktor-Faktor Yang Berpengaruh Terhadap Set Kesempatan Investasi (IOS) Pada Perusahaan Manufaktur Yang Terdaftar Di Bursa Efek Indonesia. Jurnal Inovasi dan Kewirausahaan. Volume 2 No. 1 Januari 2013 Halaman 32-41

Yuliani \& Muizuddin. 2014. Kepemilikan Blockholder, Investment Opportunity Set,Rasio Likuiditas, Dan Nilai Perusahaan. Jurnal Keuangan dan Perbankan, Vol.18, No.2 Mei 2014, hlm. 223-232

Zandi, Tahereh, Marzieh Bayat, \& Yavar Mir Abbasi. 2016. The relationship Between the Liquidity of the Stock and Stock Returns in Terms of Restrictions on the Financing of the Companies Listed in Tehran Stock Exchange. International Research Journal of Applied and Basic Sciences. ISSN 2251-838X / Vol, 10 (8): $1130-1135$. 